\title{
A Possible Anglo-Saxon Execution Cemetery at Werg, Mildenhall (Cvnetio), Wiltshire and the Wessex-Mercia Frontier in the Age of King Cynewulf
}

\author{
Andrew Reynolds
}

This chapter is offered as a small token of immense gratitude to the honorand of this volume. Barbara Yorke's work sets a standard that few are able to reach; always insightful, to the point and deeply thought-provoking. Her ability to throw new light on well-trodden material is widely acknowledged and is in many ways a function of her belief in, and lifelong engagement with, interdisciplinary approaches to the study of the early Middle Ages and the rich fruits that forays into the past of that nature can bear. Barbara has offered sage advice over the last ten years or so in a series of research collaborations at the Institute of Archaeology, UCL, both guiding and informing the Leverhulme Trust funded projects Beyond the Burghal Hidage, Landscapes of Governance and, most recently, Travel and Communication in Anglo-Saxon England. Before that, from 2000-2003, we were colleagues at the then King Alfred's College, Winchester (now the University of Winchester), where we shared our common interests. This piece therefore attempts to encapsulate the spirit of interdisciplinary enquiry by bringing together materials drawn from archaeology, written sources and place-names to reveal elements of the early medieval landscape history of a corner of north-eastern Wessex (Fig. 12.1), part of the region that has been the focus of so much of Barbara's writing and whose complicated history is encapsulated in her hugely influential Wessex in the Early Middle Ages published in 1995 . $^{1}$

The discussion begins by focussing on a brief report of human burials discovered at Mildenhall, Wiltshire in the 1950s, with more recent related discoveries, but whose possible significance, it can be suggested, has lain unrecognised until now and whose non-normative character, topographical and geographical setting prompt a wider enquiry. On the basis of written sources relating to the tenurial history of the area in which the burials were found, a case is then

1 Barbara Yorke, Wessex in the Early Middle Ages (London, 1995). 


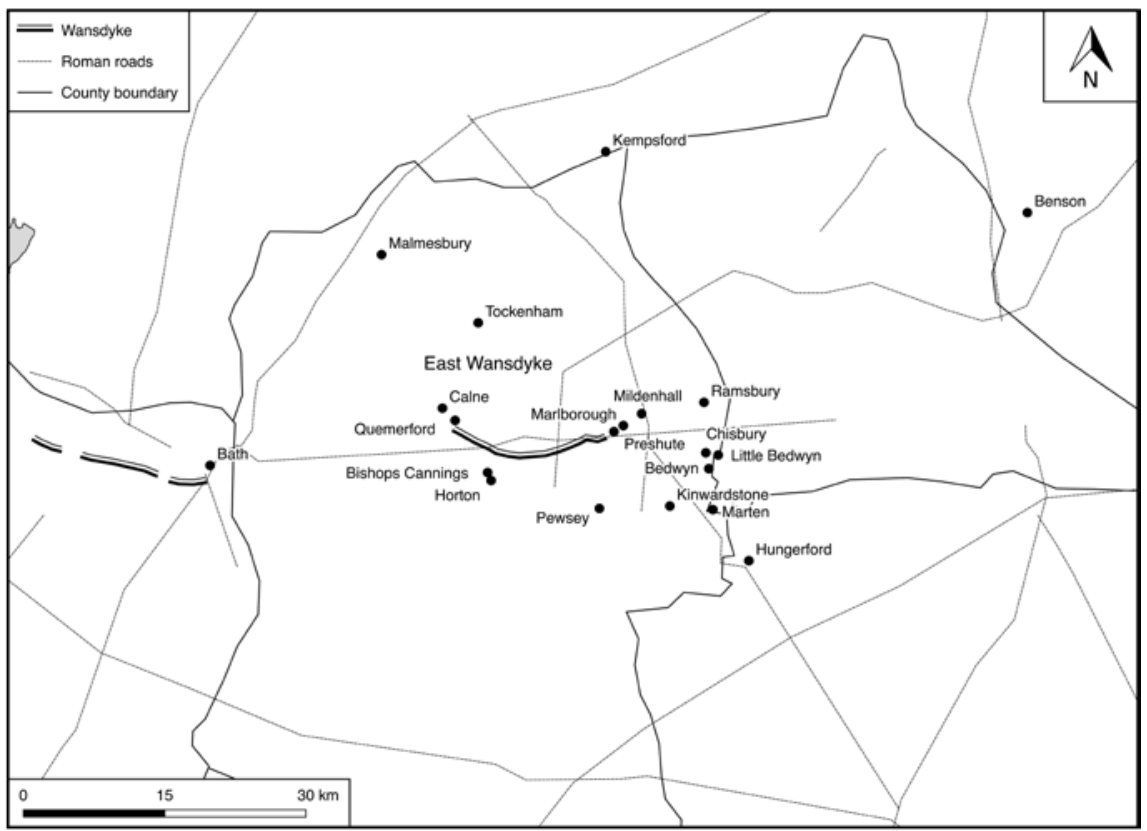

FIGURE 12.1 The Wessex-Mercia frontier region showing Wansdyke and places mentioned in the text

made for reconsidering the significance and role of the locale in the later 8th century during a period of competing claims to territory between the kingdoms of Mercia and Wessex. Overall, the paper attempts to draw a thread between a place, a region and a broader historical context, although each of these scaled discussions is arguably self-sustainable. On the way it makes suggestions about the historical and geographical context of a few problematic documents and some much debated toponyms to bring attention to a successful Wessex ruler, King Cynewulf, whose career is much neglected in the face of his contemporary, King Offa of Mercia.

\section{Human Burials at Werg}

The initial inspiration for this paper is a report of barely a page-and-a-half published in the relatively obscure Report of the Marlborough College Natural History Society in 1956 . The note in question, authored by that most active reporter of local archaeological discoveries in Wiltshire, Owen Meyrick, encapsulates in crisp prose many of the key aspects of the findings and the following summary 
draws solely upon that note as the only account of the discovery. ${ }^{2}$ The finds were made $2 \mathrm{~km}$ to the east of the Late Anglo-Saxon settlement and later town of Marlborough and $200 \mathrm{~m}$ west of the site of the former Roman town of Cvnetio, now the village of Mildenhall, in the hamlet of Werg. While the exact position of the burials excavated in 1951 was not recorded, excavations and a watching brief undertaken by Wessex Archaeology in 1997 led to the recovery of a further two graves and other disarticulated human remains re-deposited in the fills of other archaeological features (O.S. SU 21306937 ). ${ }^{3}$ These latter remains thus allow Meyrick's findings to be located with a greater degree of certainty if the two groups of burials are indeed related, which seems likely. The 1997 graves lay alongside the south bank of the River Kennet as it flows eastwards on a meandering course to the north of Cvnetio (Fig. 12.2), ${ }^{4}$ in a location that fits with Meyrick's description of the findspot as "low and quite near the present course of the Kennet, with a brook only about 20 yards away." 5 The 1997 investigations also reveal that the burials under consideration lay on the northern side of the Bath (Aquae Sulis) to Cvnetio Roman road (Margary 53), one of six routes converging on Cvnetio. ${ }^{6}$

Unfortunately, there is no plan, no photographic record, and no grave catalogue of the 1951 discoveries, but sufficient information exists to be able to appreciate the general character of the cemetery. Archaeological investigations were sparked by the finding of "a quantity of bones" on a smallholding occupied by a Mr A.C. Rhodes in May 1951. Following the realisation that the remains were human and a visit from the local police, "further investigations could be left to archaeologists," presumably led by Meyrick, which led to the recovery of eight skeletons, or parts thereof. Although the number of interments disturbed by the initial discovery is unknown, Skeletons 1 and 2 are reported as 'in large part removed'. Both bodies lay in shallow graves, one with the jaw of a small horse, and it is possible that the disturbed elements of these burials constituted the bones found in the first instance.

2 Owen Meyrick, "Romano-British Burials at Werg," Report of the Marlborough College Natural History Society 96 (1956), 19-20.

3 Nicholas Cooke, "Excavation of Roman Features and Deposits on the Outskirts of Cunetio (Mildenhall), Marlborough, in 1997," WANHM 96 (2003), 26-32.

4 The name Cvnetio is likely to derive from that of the river rather than vice-versa, although the meaning of the name is uncertain: see, A.L.F. Rivet and Colin Smith, The Place-Names of Roman Britain (London, 1979), pp. 328-29.

5 Meyrick, "Romano-British Burials," p. 20: Cooke, "Roman Features," p. 28.

6 Mark Corney, "The Romano-British Nucleated Settlements of Wiltshire," in Roman Wiltshire and After: Papers in Honour of Ken Annable, ed. Peter Ellis (Devizes, 2001), pp. 5-38, at p. 12. 


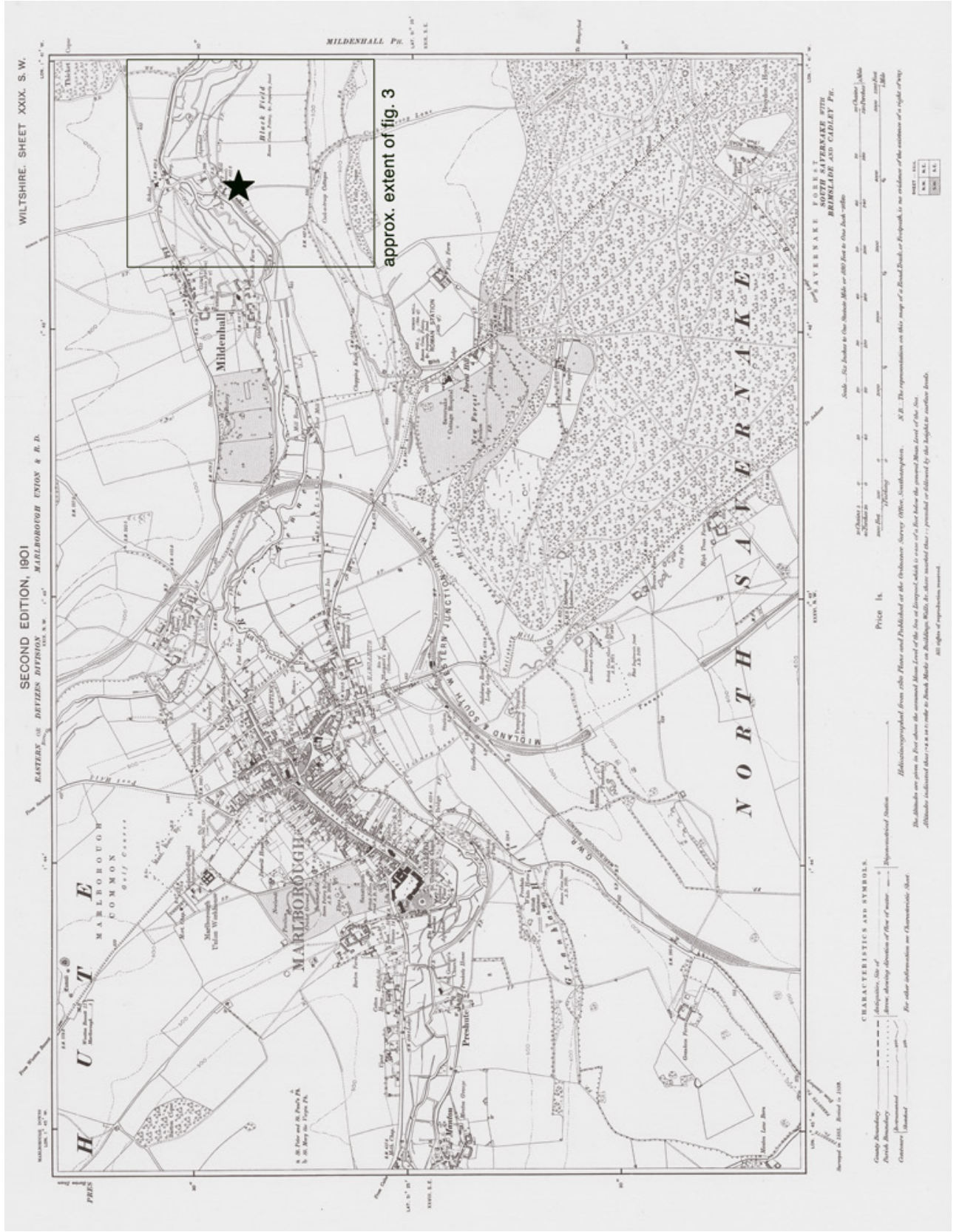

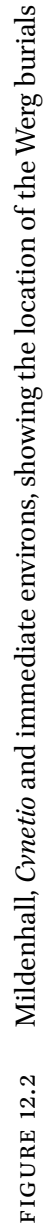


The other skeletons were found at varying depths, all less than three feet. Skeleton 3, a disturbed interment, partly overlay Skeleton 4, the latter buried with the knees flexed and "a nail lying upright at the feet". Skeleton 5 was buried face down with the head turned to one side, an ox-jaw 'resting' on the left thigh and an oyster shell by the right hand. This body partly overlay that of Skeleton 6, another burial with flexed knees, and with iron fibulae by one hand and under the chin, features that suggested a shroud burial to Meyrick. Skeleton 7 , also flexed at the knees, was found with a rim-sherd of unspecified date near the head, while Skeleton 8, again flexed at the knees, had the upper part of a large Savernake-type pot (1st century AD) near the head and a large ox bone in the grave fill. Skeleton 5 lay "north to south," the others "east to west," although the direction of the heads is not stated.

Meyrick reports that none of the skeletons showed signs of "a violent death" and indeed the remains, or at least a sample of them, were inspected by a $\mathrm{Dr}$ D.G. Roberts of the Department of Human Anatomy at Oxford, who, one hopes, would have recognised any obvious signs of trauma to the bones. Roberts reported that Skeleton 1 was that of a male aged 35-40, that Skeleton 2 was also male and aged about 30, while Skeleton 3 was an adult female; Skeletons 4 and 6 were older individuals of unspecified sex. Meyrick's report notes that Skeleton 5 was a male, but it is not clear whether that was confirmed by Roberts. One must, of course, be wary of such attributions in view of the considerable advances made in the field of human osteology since the 1950s, but one might expect an Oxford anatomist to be able to make sound judgements with regard to the sex of the individuals. That Roberts did not pronounce upon the sex of Skeletons 4 and 6 suggests the exercise of caution where, for whatever reasons, a confident assessment could not be made.

The two graves found in 1997 were disturbed interments and both lay eastwest in shallow graves, heads to the east. ${ }^{7}$ Grave 60 contained a heavily disturbed body laid supine and of undetermined sex. The grave fill contained disarticulated bone from two other individuals. Five sherds of medieval pottery initially ascribed to the grave fill are suggested by the excavator to be instead derived from a medieval ditch that truncated the grave. Grave 60 was cut by Grave 67 , further demonstrating a sequence of burials at the site rather than a single event. The grave (67) contained a much-disturbed body of undetermined sex. Disarticulated human remains were also found in several other features in close proximity to the graves and a study of the remains recovered in 1997 revealed a total of seven individuals, bringing the total number of burials so far known from the site to 15 , notwithstanding the possibility that the

7 Cooke, “Roman Features," p. 29, Fig. 2 and p. 31. 
discoveries in 1951 prior to Meyrick's intervention may have included further remains. A single cremation burial in a small pot of late 3 rd- or 4th-century date was also found in the 1997 investigation, but it lay $150 \mathrm{~m}$ away to the northeast, with no human remains or grave-like features encountered along the line of the excavation trench between it and the two graves just described.

\section{Previous Interpretations}

Interpretation of the remains is varied. Meyrick suggested a cemetery associated with "an adjacent settlement" (presumably Cvnetio), while the Victoria County History account of Mildenhall parish favours "a war cemetery, of the early Iron Age," presumably on the basis of Meyrick's likening of the apparent inclusion of joints of meat, which he interpreted as provisions "for the afterlife," to those found in the rather better-known burials of the 1st century AD excavated by Mortimer Wheeler at Maiden Castle in the 1930s and which for many years were thought of as victims of the Roman conquest. ${ }^{9}$ The Maiden Castle burials belong to the late Iron Age, however, while the early Iron Age in Britain is traditionally placed between $c .800$ and $c .400$ BC. Cooke suggested, entirely reasonably, that the finding of disarticulated human remains in two pits containing 1st- or 2nd-century pottery in the 1997 investigations indicated a Roman period cemetery. ${ }^{10}$ Again, however, the sheer volume of Roman material culture in the general area raises questions about secure dating, especially in the case of shallow features. The most recent assessment of burials of the Roman period in the county of Wiltshire places the Werg inhumations in the 'Late Iron Age to early Roman' period on the basis of the association of Skeleton 8 with Savernake Ware, while the Wiltshire Historic Environment Record lists the cemetery as undated. ${ }^{11}$

8 Jane Freeman, "Mildenhall," in $v c H$ Wilts. 12, pp. 125-38, at p. 127.

9 Meyrick, "Romano-British Burials," p. 2o; R.E.M. Wheeler, Maiden Castle, Dorset (Oxford, 1943). In fact, few of the Maiden Castle burials displayed injuries and while those that do might be victims of the local defence of the hillfort in the context of the Roman invasion of $\mathrm{AD}_{43}$, the majority are best seen as a 'normal' later Iron Age population buried over period of time; see Niall Sharples, English Heritage Book of Maiden Castle (London, Batsford, 1991), pp. 124-25.

10 Cooke, "Roman Features," p. 32.

11 Anne Foster, "Romano-British Burials in Wiltshire," in Roman Wiltshire, ed. Ellis, p. 169; Wiltshire County Council Historic Environment Record. Available at <www.wiltshire.gov. $\mathrm{uk} /$ wiltshireandswindonhistoricenvironmentrecord/wshermap.htm?a=d\&id=9721 > (accessed 3Jan 2018). 


\section{An Anglo-Saxon Execution Cemetery?}

Several points require emphasis. In view of the location of the burials in a place of dense urban settlement of the Roman period — of which more below-all of the associated finds might be viewed as residual materials unintentionally incorporated into the grave fillings. Indeed, the propensity of the locale to yield archaeological finds of the Roman period was such that the Ordnance Survey saw fit to formally annotate the field next to that within which the Werg burials were found (known locally as 'Black Field' (Blacke fyeld) since at least 1578) with "Roman Coins, Pottery, \&cc. frequently found" on its 1889 6-inch to the mile map of Marlborough and environs (Fig. 12.2). ${ }^{12}$

The Werg burials are not associated with any known burial ground of certain Roman date, save for the single cremation burial noted above which lay some distance away. A single inhumation in a lead coffin, recovered $120 \mathrm{~m}$ south of the south-east corner of Cvnetio is certainly of (late) Roman type and indicates a cemetery of that period alongside the road to Calleva (Silchester). ${ }^{13}$ While a later Roman setting for the Werg burials must remain a distinct possibility, in view of the unfurnished character of the burials, flexed aspect of certain of the bodies and proximity to Crnetio, an alternative attribution is equally possible.

Prone burials are long recognised from Romano-British cemeteries, particularly the later ones (4th century), including in urban settings, ${ }^{14}$ but they are also common finds in 'Anglo-Saxon' cemeteries. In the pre-Christian period they are found in otherwise normal community cemeteries and, from the 7th century onwards, principally in execution cemeteries of 7 th- to 12th-century date. ${ }^{15}$ If a Roman period extra-mural cemetery is less than certain, then other possibilities - a 'British' cemetery of the early post-Roman period or an early 'Anglo-Saxon' cemetery of the $5^{\text {th }}$ to $7^{\text {th }}$ centuries - should be considered if only to be ruled out. All too little is known about the nature of continuity of burial customs from the late Roman period to the early middle ages in the region, but where late Roman cemeteries once considered to run on into the early Anglo-Saxon period have been subject to detailed scrutiny, including

\footnotetext{
12 J.E.B. Gover, Allen Mawer and F.M. Stenton, The Place-Names of Wiltshire (Cambridge, 1939), p. 302; Ordnance Survey 1889, Sheet XXIX.

13 F.K. Annable, "A Coffined Burial of Roman Date from Cunetio," WANHM 72:3 (1980), 187-91; Mark Corney, "The Origins and Development of the 'Small Town' of 'Cunetio', Mildenhall, Wiltshire," Britannia 28 (1997), 337-50, at p. 346.

14 Robert Philpott, Burial Practices in Roman Britain: A Survey of Grave Treatment and Furnishing AD 43-410 (Oxford, 1991), pp. 71-73.

15 Andrew Reynolds, Anglo-Saxon Deviant Burial Customs (Oxford 2009), Chapters 3 and 4.
} 
scientific dating, for example in the Upper Thames region of Oxfordshire and in eastern England, the case for continuity has been retracted. ${ }^{16}$

A cemetery of 'Germanic' character can be ruled out on the basis of a lack of grave finds that typify such burials in the North Wiltshire area and beyond. As generally poor as early Anglo-Saxon burials in North Wiltshire are by comparison with other regions of southern Britain, they nevertheless yield materials of a sufficiently distinctive character to be able to position them in cultural terms. ${ }^{17}$ A further proposition-an unenclosed 'field cemetery' of normal community type of the middle Anglo-Saxon period ( 7 th to 9 th centuries) ${ }^{18}$-is unlikely on the basis of the aberrant Skeleton 5 , interred prone and northsouth in orientation. There is no evidence of a medieval cemetery in the immediate vicinity, at least not of churchyard-type, other than that associated with St John the Baptist, Mildenhall, $400 \mathrm{~m}$ to the west, a church that possibly preserves some 11th-century fabric. ${ }^{19}$ Interestingly, however, Mildenhall was the site of a royal prison in 1265 , with a gallows erected by a certain James de Audeberg there in $1272-73$, although its site is not known. ${ }^{20}$ While there is no evidence for the burial of execution victims beyond the 12th century at any of the excavated English execution cemeteries, with burial apparently normally taking place in monastic hospital or other especially designated cemeteries by

16 James Gerrard, "New Radiocarbon Dates from the Lynch Farm Romano-British Cemetery, Near Peterborough,” Northamptonshire Archaeology 38 (2016), 241-43; C.M. Hills and T. O'Connell, "New Light on the Anglo-Saxon Succession: Two Cemeteries and their Dates," Antiquity 83 (2009), 1096-1108.

17 While there is a sizeable body of evidence for burials of a Germanic character in Wiltshire between the $5^{\text {th }}$ and 7 th centuries, synthesized in a masterly fashion by Bruce Eagles, the general level of material culture pales in comparison to the cemeteries of the Upper Thames and other parts of southern and eastern England. See, for example, Bruce Eagles, "The Archaeological Evidence for Settlement in the Fifth to Seventh Centuries AD," in The Medieval Landscape of Wessex, ed. Michael Aston and Carenza Lewis (Oxford, 1994), pp. 13-32; Bruce Eagles, "Anglo-Saxon Presence and Culture in Wiltshire c. AD450c.AD675," in Roman Wiltshire, ed. Ellis, pp. 199-233.

18 For discussions of this kind of cemetery, largely unrecognized until the 1990s, see John Blair, Anglo-Saxon Oxfordshire (Stroud, 1994), pp. 72-73; Sam Lucy and Andrew Reynolds, "Burial in Early Medieval England and Wales: Past, Present and Future," in Burial in Early Medieval England and Wales, ed. Sam Lucy and Andrew Reynolds (London, 2002), pp. $13^{-15}$.

19 Nikolaus Pevsner and Bridget Cherry, The Buildings of England, Wiltshire (London, 1975), p. 348; Daniel Secker, "St John the Baptist, Mildenhall, Wiltshire" (unpublished typescript, 2009), 18pp. Available at <https://medievalsitesite.files.wordpress.com/2011/12/mildenhall -wiltshire-church.pdf> (accessed 12 Jan. 2018).

Freeman, "Mildenhall," p. 135. 
this time, ${ }^{21}$ there is an outside possibility that the Werg burials are related to Audeberg's instrument of death.

In conclusion, the Werg graves were shallow, nine out of ten were oriented east to west, with one north-south, while graves intercutting others demonstrate sequence and not a single episode such as a massacre or conflict event. All of these characteristics align with those exhibited by Anglo-Saxon execution burials, where east-west orientation predominates, with other orientations also observed. The flexed aspect of four of the eight interments from the 1951 excavations should not be taken as an indication of uniquely later prehistoric or Roman period custom, as it is commonly observed in cemeteries of the Anglo-Saxon period, both of the pre-Christian and Christian centuries, including execution cemeteries of the 7 th and 8th centuries and later. ${ }^{22}$ Thus, we have a cemetery with a clear set of characteristics, but which is otherwise undated if the associated, likely residual, remains are discounted as secure dating evidence. A consideration of a possible chronological setting for the burials must therefore draw upon wider observations, but an execution cemetery somewhere in the $7^{\text {th- }}$ to 12 th-century range is a strong contender.

\section{Location}

The topographical setting of cemeteries in general can often reveal as much about their character and type as the mode of burial customs found within them. In the case of execution cemeteries, three particular aspects stand out as defining characteristics: proximity to routeways, boundaries and pre-existing monuments. The location of the burials alongside one of the routes leading into the town of $C$ vnetio has already been noted and the place was clearly a key crossing point of the Kennet. No discussion of Cvnetio read in the preparation of the current piece, however, considers the possibility of bridges over the river Kennet during the Roman period. Given the key location of the place and the convergence of six major roads upon the Roman town (Fig. 12.3), the likelihood of at least timber bridges, perhaps with stone abutments, ought to be considered both to the north and east of the town where roads cross the river on the

\footnotetext{
21 Reynolds, Deviant Burial, pp. 245-46.

22 There is an extensive literature on the interpretation of flexed burials in early AngloSaxon cemeteries, which largely concerns questions of the 'ethnic' attribution of persons found so buried. See, Sam Lucy, The Anglo-Saxon Way of Death (Stroud, 2000), pp. 80-81. This discussion need not detain us further here, beyond the observation that the custom is observed over a long period, from later prehistory onwards, with fluctuations and nuances.
} 


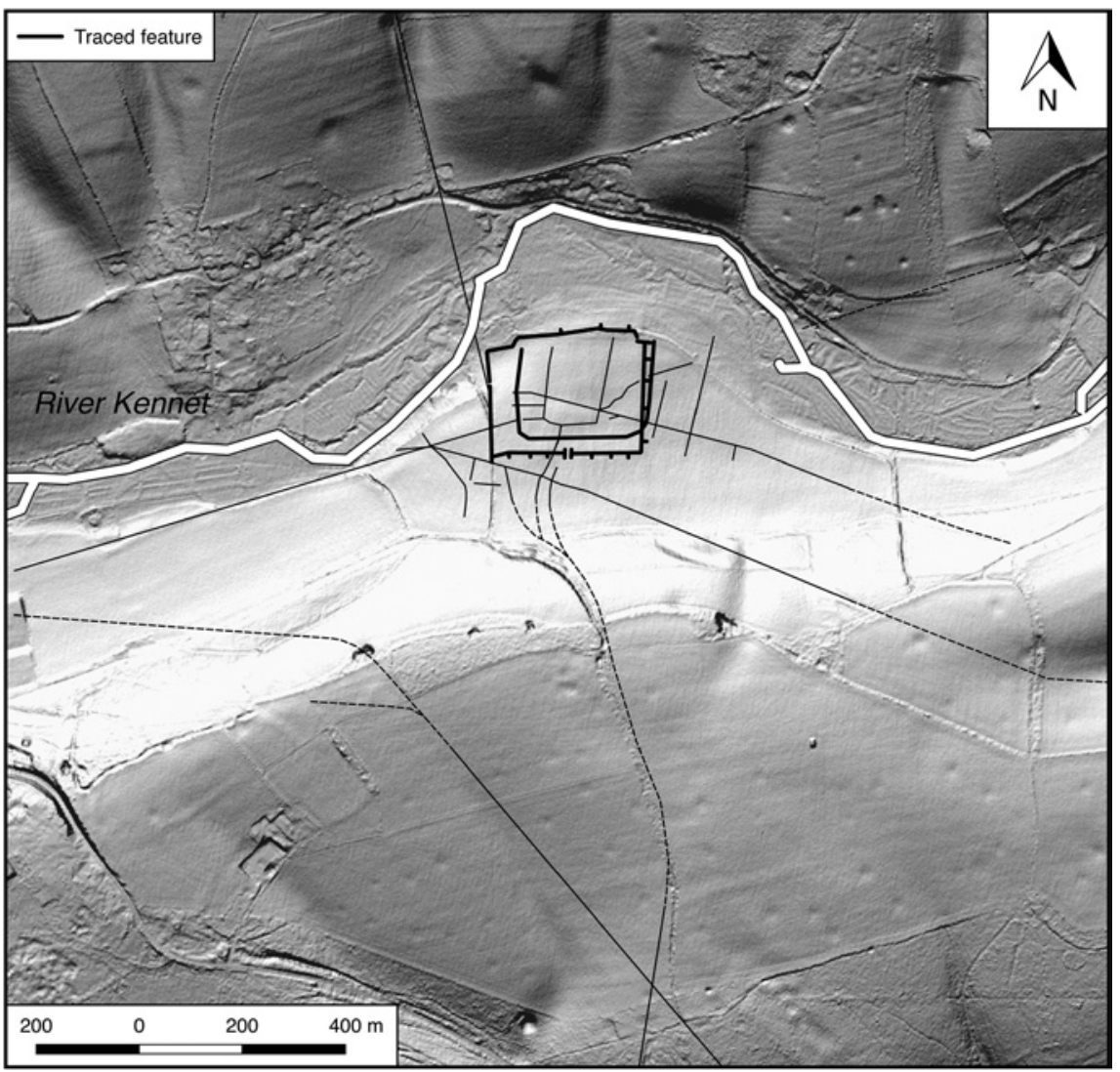

FIGURE 12.3 Cvnetio and its place in the Roman road network

way to Cirencester (Corinium) via Margary 43 and possibly Alchester via Frilford respectively. ${ }^{23}$ The river is narrow relative to watercourses elsewhere that had roads carried across them by bridges - for example Staines (Pontes), where the Roman name indicates more than one bridge, very likely a function of the confluence of several water courses there flowing into the Thames. ${ }^{24}$

Whether there were bridges or not, the locale was evidently a nodal point in the communication network of the region, although quite how long the various elements of the Roman road network survived in use into the Anglo-Saxon period is unknown. On the basis of a visual inspection of Ordnance Survey maps, it can be seen that the Roman road network in North Wiltshire at least,

23 Corney, “Origins," p. 346.

24 Phil Jones and Rob Poulton, Roman and Medieval Staines: the Development Of The Town (Woking, 2010). 
survives in a piecemeal fashion. The East-West Mildenhall to Bath (Aquae Sulis) road leaves very little trace in the modern pattern of routes, beyond a general reflection of a corridor of movement on that axis. ${ }^{25}$ From this observation, it might be suggested that the network of modern roads, at least the principal routes between the central places of the late Anglo-Saxon period, formed as those places crystalized into key centres of marketing and settlement. In other words, the Roman system appears to have been retained in a selective way, although quite what means of long-distance communications preceded the imperial network is far from established. Certain long distance routes of Roman origin, in particular those running north-south and connecting what became Mercia with Wessex have left a stronger sense of continued use-evident by their persistence up to the period of Ordnance Survey mapping - than east-to west routes. This is an interesting issue, which requires much more discussion than is possible here, but it does suggest that key points in the landscape of Wessex, like Cvnetio, will have retained importance as strategic nodes. The Werg burials perhaps find a setting in this context.

The most important east-west routes are those running parallel to the north and south of the River Kennet, following the river valley, and which link, to the north, Ramsbury (the seat of a Bishop between 909 and 1058) to Marlborough and, to the south, Marlborough to Hungerford. ${ }^{26}$ Marlborough appears to be a late Saxon or later development as a town, while Hungerford is absent from the Domesday Survey; potentially both places are relatively late arrivals to the settlement geography of the area and the link between Mildenhall and Ramsbury is perhaps the earlier of the two routes. A key crossing point over the Kennet, linking the routes just discussed with the Roman roads converging on Crnetio, seems to have been at Werg on the basis of both the configuration of the road pattern found on the earliest mapping of the locale and the existence of a bridge there by the 16 th century, ${ }^{27}$ where a connection across the river is made with the two Roman roads that converge $1.5 \mathrm{~km}$ south of the river and which themselves connect with the river via a route known as Cock-a-troop lane (Fig. 12.3), first recorded in 1257 as Crokerestrope, a name that derives either from the former existence of potters there or, more likely, to the commonality of Roman pottery in the ground round about. ${ }^{28}$ It is of interest that Cock-a-troop Lane now passes directly over the south-west corner of the Roman walled circuit, although it re-emerges from within the walls close to the known entrance in

O.G.S. Crawford, Archaeology in the Field (London, 1953), pp. 67-73.

Crawford, Archaeology, p. 73, Fig. 7.

27 Andrews and Dury's Map 1773; Freeman, "Mildenhall," p. 127.

28 Gover et al. Wiltshire, p. 301. 
the east wall. It would appear that the route originally ran up to the monumental south gate into the town, but that it was then diverted at some later juncture, perhaps when the south gate became impassable due to collapse: there may have been a breach at the south-western corner that facilitated passage through the ruins.

That Marlborough's two parishes have been carved out of Preshute parishthe latter church being the mother (minster) church of Marlborough -indicates that the pattern of local estate boundaries in the vicinity of Werg was at least partly altered in the late Anglo-Saxon period. ${ }^{29}$ While the Werg burials themselves lie in the centre of the parish of Mildenhall as mapped in 1889, they do bear a close relationship to boundaries at the level of the tithings of Mildenhall (Fig. 12.4). Three in all, the tithings were those of Mildenhall, Poulton and Stitchcombe, all of which find entries in the Domesday Survey, of ten hides apiece for the first two estates, and only a hide for the last, ${ }^{30}$ although in $183^{8}$ the latter two covered $c .800$ acres and $c .1000$ acres respectively, with Mildenhall tithing at $c .2200$ acres. ${ }^{31}$ The burial site lay on the boundary between Mildenhall and Stitchcombe tithings, the River Kennet marking the division between the two, ${ }^{32}$ but what of the possible antiquity of the these divisions? Quite how far back the antiquity of Mildenhall's tithings lies is unknowable, but the tenurial history of Mildenhall is rather better documented than most other parcels of land prior to the Domesday Survey and an 8th-century horizon, at least, can be established.

The earliest written record of Mildenhall is an entry in the Liber Terrarum of Glastonbury Abbey, a mid-13th-century transcription of an earlier (perhaps late 1oth- or 11th-century) cartulary. ${ }^{33}$ The list records the granting of Mildenhealh by the West Saxon king Cynewulf to a certain Bica. Commentators on the grant, which cannot be dated any more closely than to the duration of that king's reign (757-86), note that forgery of a grant to a lay-person is most unlikelywith most forgeries being the product of monastic scriptoria laying false claim to lands - and in any case, a further grant of land to Bica, of an estate at Little Bedwyn in 778 is of undoubted authenticity, surviving as it does as a single sheet

29 H.C. Brentnall, "The Origins of the Parish of Preshute," WANHM 53 (1950), 294-310, at p. 275 .

3о DB Wilts. 7:7; 27:19; 67:48.

31 Freeman, "Mildenhall," p. 125.

32 Freeman, "Mildenhall," p. 125.

33 For a discussion of this list and its dating, see Leslie Abrams, Anglo-Saxon Glastonbury: Church and Endowment (Woodbridge, 1996), pp. 13-18. 


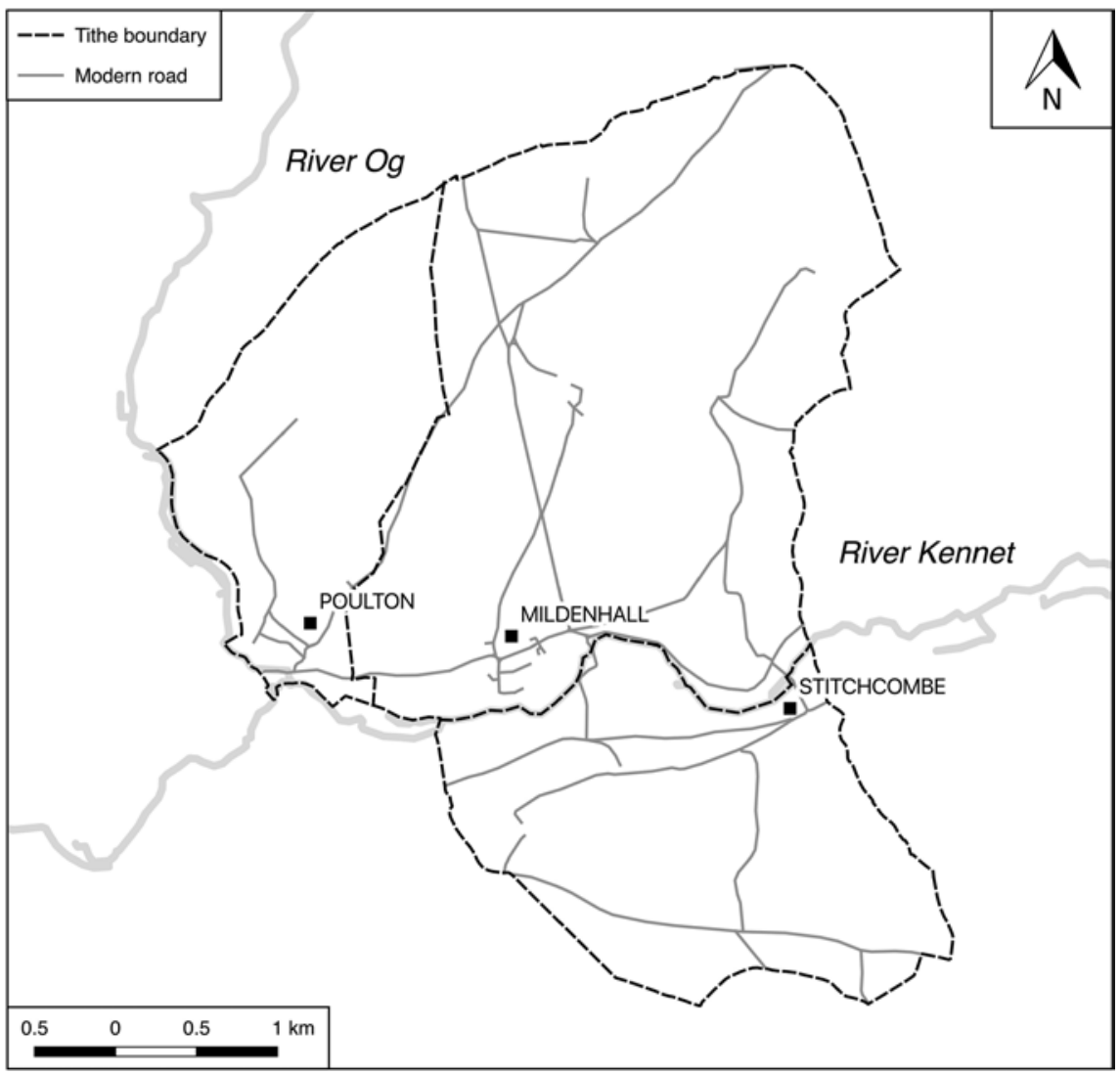

FIGURE 12.4 The parish of Mildenhall showing local routes and tithing boundaries

copy, perhaps contemporary but arguably later on palaeographical grounds. ${ }^{34}$ The implications of these two grants to Bica are further explored below.

Land at Mildenhall finds mention in several other pre-Conquest sources. An Old Minster charter in the 12th-century Codex Wintoniensis records an exchange of lands dated $801 \times 805$ between Bishop Eahlmund of Winchester and a certain Byrhtelm, probably Bica's heir, whereby the bishop received a combined total 33 'manentes' comprising four estates, including at both Mildenhall and Bedwyn, ${ }^{35}$ although the extent of the lands is not stated and it is possible that the Mildenhall parcel might have comprised either of the two larger tithings found in the Domesday Survey. In any case, it seems clear from a later

34 S 264; Heather Edwards, The Charters of the Early West Saxon Kingdom, BAR Brit. Ser. 198 (Oxford, 1988), p. 59 .

$35 \quad$ S 1263; H.P.R. Finberg, The Early Charters of Wessex (Leicester, 1964), p. 72. 
affirmation of the granting of 15 hides at Mildenhall to Glastonbury by King Edgar (946×955), found in the (not unproblematic) Glastonbury source De antiquitae Glastonie ecclesie, a 12th-century text in origin with subsequent additions, that either the extents of these lands or their hidage assessments fluctuated over time. ${ }^{36}$

Besides being located on a boundary of at least 8th century date, a link between the Werg burials and an ancient monumental setting is obvious. Elsewhere, a series of Anglo-Saxon execution cemeteries is located in close proximity to former Roman towns, some of which became important AngloSaxon towns (for example, Winchester and Old Sarum), and a number of others where execution cemeteries can be shown to predate urban occupation of the Anglo-Saxon period (such as Cambridge and Staines). ${ }^{37}$

The evidence of local place-names, however, brings another perspective to the findspot of the Werg burials with a bearing on the interpretation of the remains. Despite being identical with Old English 'wearg' (villain, felon, scoundrel), the place-name Werg is apparently better received as meaning 'willow' with similar examples found not far away in Berkshire. ${ }^{38}$ In view of the archaeological discoveries and their topographical setting, the possibility that Old English 'wearg' is here preserved must remain a distinct possibility. Of particular significance, however, is the name of the field, Nickamore Field, within which the burials were found and of the immediate locale. First recorded in 1272 as Nikerpole, the name is again recorded in the 16th century as Nicapooles Croft. ${ }^{39}$ Somewhat bizarrely, if not entirely without relevance, the editor of the 1956 Marlborough College Report, E.G.H. Kempson, appreciated the significance of the name of the field within which the burials lay in an addendum to Meyrick's report, noting that "Possibly on an earlier occasion corpses may have been disturbed and ghosts seen." ${ }^{40}$ The significance of the field-name is its incorporation of the 'nicor', a water-demon that features in the Beowulf epic, no

$3^{6}$ Abrams, Glastonbury, pp. 175-76.

37 Reynolds, Deviant Burial, pp. 118-20 and p. 147; Craig Cessford, with Alison Dickens, Natasha Dodwell and Andrew Reynolds, "Middle Anglo-Saxon Justice: The Chesterton Lane Corner Execution Cemetery and Related Sequence," Archaeological Journal 164 (2007), 192-226; Graham Hayman and Andrew Reynolds, "A Saxon and Saxo-Norman Execution Cemetery at 42-54 London Road, Staines," Archaeological Journal 162 (2005), 215-55.

38 See, R.D. Fulk. 'Old English Werg-, wyrg- 'accursed," Historical Linguistics, 117 (2004), $315^{-22}$. I am grateful for John Baker's comment on this name and for supplying references. Margaret Gelling, The Place-Names of Berkshire I (Cambridge, 1973), p. 125; Margaret Gelling, The Place-names of Berkshire II (Cambridge, 1974), pp. 311 and 319. See also Reynolds, Deviant Burial, pp. 225-27.

39 Gover et al., Wiltshire, p. 499.

40 Meyrick, "Romano-British Burials," p. 20. 
less. ${ }^{41}$ Semple notes water-demons in her consideration of pre-Christian cult practice in Anglo-Saxon England, referencing also the Knucker's Hole, Sussex, ${ }^{42}$ and it seems clear from the association of virtually all other known AngloSaxon execution cemeteries with features of an earlier age with potentially mythical connotations (for example, barrows and linear earthworks) that the two phenomena go together. While one might query the ghosts of the Report's Editor, a spot with demonic associations might either motivate or result from the location of a place for the despatch and burial of social outcasts. As a final note on the matter, the ruins of Cvnetio may well have inspired an other-worldly reaction from local people in the post-Roman period. Although the fragmentary 1oth-century Exeter Book poem known as The Ruin suggests that this might take the form of reflections of wonderment rather than fear, ${ }^{43}$ casting a common notion from a single source is sketchy at best. It is of interest in this light that a further example of a 'nicor' name is found in the Nicarpool, just south of the Roman city of Lincoln. ${ }^{44}$ It might also be significant that the name of Poulton tithing means 'the farm by the pool'; ${ }^{45}$ perhaps so-called after its proximity to a body of water of such local notoriety that it required no further qualifying appellation.

\section{The Fate of Cvnetio}

Over thirty years after the discovery at Cvnetio of the largest hoard of Roman coins found in Britain (in a large pot and a lead container between them holding nearly 55,000 coins of the 3rd century AD), and in the light of Mark Corney's painstaking plotting of the evidence from aerial photographs published in the late 1990 s, ${ }^{46}$ Channel Four's Time Team undertook large-scale surveys and sample excavations in order to bring a greater understanding to the site. A programme about the work was broadcast on 23 May 2010, entitled "Potted History," in Series 17 of Time Team. The investigations revealed much of interest,

41 For references to occurrences of the nicor in Old English texts, including Beowulf, see Joseph Bosworth and T. Northcote Toller, An Anglo-Saxon Dictionary (Oxford, 1898), p. 717. Sarah Semple, "In the Open Air," in Signals of Belief in Early England: Anglo-Saxon Paganism Revisited, ed. Martin Carver, Alex Sanmark and Sarah Semple (Oxford, 2010), pp. 21-48, at p. 30.

44 Francis Hill, Medieval Lincoln (Cambridge, 1948), p. 35.

45 Gover et al., Wiltshire, p. 301.

46 Edward Besly and Roger Bland, The Cunetio Treasure: Roman Coinage of the Third Century $A D$ (London, 1983); Corney, “Origins," p. 342, Fig. 3. 
but nothing datable to the post-Roman period beyond a few sherds of later medieval pottery ${ }^{47}$ Although stone buildings within the town were shown to have been in a state of collapse and/or demolition and had been robbed within the Roman period, investigation of the defences in several places-following a series of small cuttings made in the 1950s and 196os_-failed to establish a chronology for the destruction and removal of the town wall. ${ }^{48}$ It must be significant, however, that the stone defences were not built until after $c . \mathrm{AD} 360$, perhaps even as late as $c . \mathrm{AD} 380$-in fact they are the latest known defences of this kind to have been built in the civilian area of Roman Britain ${ }^{49}$ - and thus likely to have been in fine condition by the early $5^{\text {th }}$ century and the apparent abandonment of the place. It is possible that stone buildings within the town were demolished to provide building materials for the defences by analogy with sites elsewhere in the province.$^{50}$ Corney suggests that by this time $\mathrm{Cvne-}$ tio was a local centre of administration, a tax collection centre and a base for comitatensian (mobile field army) forces in the region. ${ }^{51}$

We have already noted that $C$ vnetio was the focus of no less than six Roman roads, making it a key nexus for travel and communication in central southern England, not just in the Roman period, but after too-at least until that arterial network failed to serve the economic and settlement patterns that followed. Here is not the place to provide a full survey of the early medieval archaeology of the region, as such can be found in detail elsewhere, ${ }^{52}$ but in a nutshell the regional axes of action in the $5^{\text {th }}$ and 6 th centuries can be placed in the Upper Thames and along the south coast, with both regions facing a cultural watershed with Western Britain which lasted into the 7 th century. By the second half of the 7th century, what became the kingdom of Wessex developed in the region between the Thames, the Solent and Selwood forest in the west.

As argued elsewhere, a marked disjuncture between Roman towns and locations that developed into central places during the Anglo-Saxon period can be

47 [Anon.], Cunetio Roman Town, Mildenhall, Marlborough, Wiltshire: Archaeological Evaluation and Assessment of Results (Salisbury, 2011). Wessex Archaeology Report reference: 71509.01.

48 Anon., Cunetio, pp. 24-25.

49 Corney, "Origins," p. 346.

5o Corney, "Origins," p. 349.

51 Corney, "Origins," p. 349.

52 Eagles, "Archaeological Evidence"; Eagles, "Presence and Culture." Dr Eagles' papers are published in fully revised and updated form as an interlinked collection: see Bruce Eagles, From Roman Civitas to Anglo-Saxon Shire: Topographical Studies on the Formation of Wessex (Oxford, 2018). 
observed in the Marlborough area. ${ }^{53}$ This pattern can be traced along a corridor which broadly follows territories disputed between the kingdoms of Mercia and Wessex between the later 7th and earlier 9th centuries AD, in other words between the estuary of the Bristol Avon and the Thames in the Staines area. ${ }^{54}$ This pattern contrasts with many other parts of Britain where Roman centres re-emerged as places of importance as the Anglo-Saxon period progressed. What happened to Cvnetio, when did it happen and why?

Following sporadic explorations since the 19th century, detailed studies of Crnetio have succeeded in plotting the extent of the site, including two phases of defences; an earthwork enclosure of early Roman period, which was then enclosed within a substantial wall of flint and chalk faced with oolitic limestone, furnished with at least three gates and, at the last count, some 17 bastions-all-in-all a fortification covering $7.5 \mathrm{ha}^{55}$ and a place that by anyone's measure would have been an imposing fortress in the late Roman landscape and after. Why is there now nothing there visible above ground? Was Cvnetio visible as a walled enclosure when Marlborough was developed as a town? What social, political and economic phenomena led to the total erasure of such a substantial place? A possible indication of the residual significance of Crnetio and locale is the albeit tenuous evidence for a chapel in Mildenhall parish at an unknown place called 'Selk', which may have lent its name to the Domesday Hundred of Selkley, perhaps as a function of its location having been the meeting place of the hundred, although other locations are perhaps more likely. ${ }^{56}$ Archaeological finds of early medieval date in Mildenhall parish are limited to a couple of burials of 6th- and 6th/7th-century date, a saucer brooch of 6th-century date, a sherd of chaff-tempered pottery, a spearhead, and a late Saxon penny of Æthelred II (978-1016). ${ }^{57}$

53 Joshua Pollard and Andrew Reynolds, Avebury: The Biography of a Landscape (Stroud, 2002), Chapter 6.

54 Andrew Reynolds and Alexander Langlands, 'Social Identities on the Macro Scale: A Maximum View of Wansdyke', in People and Space in the Middle Ages, 300-1300, ed. Wendy Davies, Guy Halsall and Andrew Reynolds (Turnhout, 2006), pp. 13-44, at p. 42.

55 Corney, "Origins," pp. 343-44; Corney, "Nucleated Settlements," p. 17.

56 Freeman, "Mildenhall," p. 125; Andrew Reynolds, 'From Pagus to Parish: Territory and Settlement in the Avebury Region from the Late Roman Period to the Domesday Survey', in The Avebury Landscape: Aspects of the Field Archaeology of the Marlborough Downs, ed. G. Brown, D. Field and D. McOmish (Oxford, 2005), p. 172.

57 Simon Draper, Landscape, Settlement and Society in Roman and Early Medieval Wiltshire (Oxford, 2006), p. 156. 
If Marlborough was planned as a fortified settlement in the late gth century, as Jeremy Haslam has agued, ${ }^{58}$ then $C v n e t i o$ must have been dilapidated to the extent that its refurbishment was simply too big a task, otherwise it would surely have been refortified, or it had been robbed of its materials to a degree that reconstruction simply was not viable. That it was not re-occupied may suggest that Marlborough's urban character came very late in the Anglo-Saxon period if not after, perhaps during the floruit of urban growth that occurred in Britain from the 12th century. The presence of a castle at Marlborough by no means supports the existence of an urban settlement there at the time it was built and indeed other castles in Wiltshire are found in non-urban settings (for example, Devizes (initially), Wardour and Ludgershall). All too little is known about Marlborough's development from an archaeological perspective-in fact almost nothing - but there is currently no evidence to support a late gthcentury urban foundation.

Haslam's model for urban development in North Wiltshire, views Marlborough and Hungerford outplaying Ramsbury and Bedwyn in the late AngloSaxon period and Ramsbury succeeding Cvnetio as the base of local power at "an early date". ${ }^{59}$ While Bedwyn's moneyer Cild evidently moved to Marlborough in the reign of William the Conqueror, ${ }^{60}$ Marlborough is not designated as a borough in the Domesday Survey, whereas Bedwyn is. ${ }^{61}$ Notions of the degree of urbanity in Anglo-Saxon England have been much debated in recent years, with views ranging from it being a veritable urban crucible far earlier in comparison to its regional (Welsh, Scottish and Irish - to use modern geographical terms) neighbours, to a part of Europe that shares rather more in common with urban trajectories found across the European area; namely an urban development that aligns with a 12th-century upward turn there as elsewhere. ${ }^{62}$

$5^{8}$ Jeremy Haslam, "The Towns of Wiltshire," in Anglo-Saxon Towns in Southern England, ed. Jeremy Haslam (Chichester, 1984), p. 101; Jeremy Haslam, The Landscape of Late Saxon Burhs and the Politics of Urban Foundation', in The Material Culture of the Built Environment in the Anglo-Saxon World, ed. Maren Clegg Hyer and Gale R. Owen Crocker (Liverpool, 2017), pp. 181-215, at pp. 202 and 213.

59 Haslam, "Wiltshire," at pp. 94-102.

6o F. Elmore Jones, "A Supplementary Note on the Mints of Bedwyn and Marlborough," in Mints, Dies and Currency: Essays in Memory of Albert Baldwin, ed. R.A.G. Carson (London, 1971), pp. 121-27.

$61 \quad D B$ Wilts. 1:23i; 1:2; 23 i.

62 Andrew Reynolds, "Spatial Configurations of Power in Anglo-Saxon England: Sidelights on the Relationships between Boroughs, Royal Vills and Hundreds," in Power and Place in Europe in the Early Middle Ages, ed. Jayne Carroll, Andrew Reynolds and Barbara Yorke (Oxford, 2019), Proceedings of the British Academy 224, pp. 436-455. 
Perhaps the robbing of Cvnetio's walls largely took place between the 9th and 12th centuries as a function of their quarrying during the rise of parish churches during this time, or perhaps for the surfacing of roads in the late Saxon period or later. Before this cultural horizon, it is fundamentally problematic to visualise how and why a major fortification was dismantled in a period where all buildings, with the exception of major churches (minsters), were of timber. Nearby minsters incorporating limestone include Avebury, while Roman sculpture is present at St Mary's Marlborough and at Stitchcombe, but the number of local minsters - and not least the availability of building stone to be plundered from the multiplicity of ruined Roman buildings in the landscapedo not adequately explain the demise of Cvnetio.

\section{The Wessex-Mercia Frontier}

At this juncture it is useful to draw together several threads; gallows, grants of land, and the wider setting of both in relation to the frontier between Wessex and Mercia. If the Werg burials are indeed pre-12th-century execution victims, then we might expect the gallows at which they met their fate to be in immediate proximity on the basis of similar cemeteries elsewhere. ${ }^{63}$ While the gift of Mildenhall to Bica is known only by its incorporation in Glastonbury's Liber Terrarum ${ }^{64}$ students of Anglo-Saxon landscape history are more fortunate with regard to Cynewulf's grant of Little Bedwyn to him, for it includes a detailed boundary clause in Latin, with place-names given in Old English; in fact, it is the "earliest surviving example of such a detailed perambulation." 65 Of particular relevance to our discussion here is that the Bedwyn bounds make reference to the earliest documented gallows in Anglo-Saxon England using the Latin term 'gabulos'. It is a matter of not inconsiderable interest that, according to the boundary clause, the Little Bedwyn gallows lay adjacent to a mark that the locals (ruricolis) called the 'ancient monuments' (antiqua monumenta) at the 'holly stumps' (holenstypbum). This is an unusual turn of phrase, to say the least, that prompted another Wiltshire antiquary, G.M. Young, to comment on the possible cultic significance of the name, especially as the spot mentioned in the charter is that occupied since at least the early 19th century by Harrow Farm, ${ }^{66}$ the latter name possibly derived from Old English 'hearg'

63 Reynolds, Deviant Burial, Ch. 4.

64 Abrams, Glastonbury, p. 175.

65 Edwards, Wessex, p. 61.

66 G.M. Young, "The Antiqua Monumenta of Bedwyn," WANHM 45 (1924), 525-27. 
(temple/shrine), although the name is not attested before $1820 .{ }^{67}$ While the bounds have been studied in detail by Crawford, and the authenticity of the Mildenhall grant bolstered by the existence of the Bedwyn charter, ${ }^{68}$ any suggestion in the literature of a further relationship between the two grants ends there.

Of central importance here, is that the estate of little Bedwyn includes a fortification that features elsewhere in written sources as a nodal place in the early history of Wessex: the cissanbyrig (Chisbury) of the Burghal Hidage and the Abingdon Chronicle. ${ }^{69}$ That both lands were gifted to the same beneficiary, both potentially with gallows, and that both included sites of nodal importance in terms of their connectivity and defensible capacity has to-date passed without mention as far as I have been able to establish.

Further, given the comparative rarity of grants by Cynewulf, it can be suggested that something more than the reward of a faithful retainer lay behind the gifting of two estates to one man. While the militarised nature of the frontier has been considered in detail in two previous accounts, ${ }^{70}$ further possibilities can be proposed. To begin with, it might be argued that the granting of lands to Bica was part of a strategic plan to bolster the frontier with Mercia during a period of the latter's ferocious expansionist policy and ongoing territorial claims on the part of both kingdoms. Grants of land in North Wiltshire were made under both Mercian and West Saxon auspices in the second half of the 8th century-as they were along the broader frontier between the two kingdoms in the preceding century during the period of the foundation of the Thames valley minsters. ${ }^{71}$ The power struggle in this extensive regionBerkshire and Wiltshire north of the Wansdyke-has been elucidated by Barbara Yorke, who notes the key horizons thus: ${ }^{72}$ following a rebellion by the West Saxon King Cuthred in 750 in the face of earlier land-grabbing by

67 Gover et al., Wiltshire, xiv, p. 346.

68 O.G.S. Crawford, "The Anglo-Saxon Bounds of Bedwyn and Burbage," WANHM 41 (1921), 281-301; Edwards, Early Wessex, p. 72-73; Abrams, Glastonbury, p. 175-76.

69 A full discussion of the naming of Chisbury and its role in the defence of the Kennet valley, particularly in the 9th to 11th centuries, can be found in John Baker and Stuart Brookes, Beyond the Burghal Hidage (Leiden, 2013), pp. 226-29; John Baker and Stuart Brookes, "From Frontier to Border: the Evolution of Northern West Saxon Territorial Delineation in the Ninth and Tenth Centuries," ASSAH 17 (2011), 108-23.

$70 \quad$ Reynolds and Langlands, "Maximum View"; Baker and Brookes, Burghal Hidage, Chapter 4.

71 Frank Stenton, The Early History of the Abbey of Abingdon (Reading, 1913), pp. 9-18 and pp. 49-50.

72 See Yorke, Wessex, pp. 62-64 for a full account. 
Æthelbald of Mercia, Cuthred's immediate successor Cynewulf, in the first year of his reign (and that of Æthelbald's murder), attested a grant of land by Æthelbald of Tockenham in North Wiltshire to Malmesbury. ${ }^{73}$ From 758 onwards, however, Cynewulf granted lands widely in Wiltshire and beyond. Although one of his earliest charters (of $75^{8}$ ) is confirmed by King Offa $(757-96),{ }^{74}$ others betray little or no sense of Mercian overlordship. In 779 , only a year after the Little Bedwyn grant, Cynewulf lost a fight with the Mercians, now ruled by Offa, at Bensington on the River Thames in Oxfordshire. ${ }^{75}$ From that point until a further battle in 802 - this time between men from Wiltshire and from the kingdom of the Hwicce - at Kempsford in Gloucestershire, also on the River Thames, West Saxon power in the border region was subjugated. From 802 onwards, however, at least Northern Wiltshire and Somerset became permanent territorial gains for Wessex. ${ }^{76}$

As argued elsewhere, at least the naming and conception as a unified frontier of the two earthworks known as Wansdyke with the Bath (Aquae Sulis) to Mildenhall (Cvnetio) Roman road providing the link between the two, makes sense in the context of Wessex firming up-perhaps for the first time in such a dramatic fashion-its border with Mercia. The 'Wansdyke Frontier' formed a veritable comparator to its Mercian counterpart, Offa's Dyke, in several ways, prompting the question of which is the earlier of the two artefacts? Offa's Dyke is perhaps named after the heroic ancestor (the Offa found in the Mercian Royal Genealogy listed in the Anglo-Saxon Chronicle entry for 757 in certain recensions among other places). Indeed, it was the ingenious suggestion by Barbara Yorke that the 8th-century king Offa took his own name and that of his dyke from his ancestor that inspired a similar view of the Wansdyke by the author of this paper and one of the editors of this collection. ${ }^{77}$ Such a process might be read as both ideological in intent, by engaging a workforce in a collective enterprise whose physical outcome was heavily culturally loaded in terms of its naming (after Woden, that former deity transmogrified into an ancestor in the West Saxon Royal Genealogical List), and original in its organisational capacity (perhaps through the much debated use of labour by obligation). ${ }^{78}$

If Cynewulf's two grants to Bica were strategic as well as reward-driven in nature, all too little if anything has been identified about what else might have

\footnotetext{
$73 \quad \mathrm{~S} 96$.

74 S 265 .

75 The location of which perhaps suggests that Cynewulf took the fight to Offa.

76 Yorke, Wessex, p. 91.

77 Barbara Yorke, "The Origins of Mercia," in Mercia: An Anglo-Saxon Kingdom in Europe, ed. Michelle P. Brown and Carol A. Farr (London, 2005), pp. 16-17; Reynolds and Langlands, "Maximum View," p. 34.

Yorke, Wessex, p. 91.
} 
comprised such a defensive effort in the face of Mercian land grabs beyond Wansdyke, but perhaps the grants of Mildenhall and Little Bedwyn provide hints: key landscape locales along the frontier were placed into the hands of faithful and powerful men like Bica. ${ }^{79}$ Although Mercia has long been known through an examination of its charters to have exacted military obligations (trinoda necessitas) from beneficiaries of land grants from the mid-8th century, ${ }^{80}$ in Wessex the obligation of military service by the land-owning classes appears to have been automatic at this time. ${ }^{81}$ It is useful at this point, then, to reflect on certain other charters belonging to this period issued in the name of Cynewulf, although these documents have among them particular problems of attribution and location.

Among possible grants of Cynewulf in the Glastonbury archives are three problematic charters, relating to lands at Cynemersforda, Horutone and Mertone, all grants to unnamed laymen. ${ }^{82}$ None of these estates is securely located, with suggestions offered largely on the basis of modern place-names, which in certain cases present a range of options. The spelling of the name of the grantor of the Horutone and Mertone grants can be read as either Cynewulf of Wessex or Coenwulf of Mercia (796-821). There is, however, only one definite charter in Coenwulf's name among the Glastonbury documents, ${ }^{83}$ while by contrast a number can be attributed unequivocally to Cynewulf, which may lend weight to a Cynewulf association for the problematic grants. Possible identifications for the estates in question are that Cynemersford and Horutone equate to Quemerford, near Calne and Horton, near Bishops Cannings. Mertone has been suggested to lie in various southern English counties, but a case can be made for the location of the Mertone estate at Marten in Wiltshire, of which more below. If these are Cynewulf charters, then it might be argued that the North Wiltshire locations are likely as each lies along the Wessex-Mercia frontier and in two cases immediately adjacent to large royal estate centres of the house of Wessex (Quemerford/Calne and Marten/Bedwyn, with Horton

79 An interesting discussion of a mid-9th-century Mercian charter (S199) of King Berhtwulf $(840-52)$ considers a grant of land to a thegn on the northern border of the Hwicce in social and political terms, see: Dominic Goodall and Andrew Wareham, "The Political Significance of Gifts of Power in the Khmer and Mercian Kingdoms," Medieval Worlds 6 (2017), 156-95, p. 162.

$80 \quad$ Nicholas Brooks, "The Development of Military Obligations in Eighth- and Ninth-Century England," in England Before the Conquest: Studies in Primary Sources Presented to Dorothy Whitelock, ed. Peter Clemoes and Kathleen Hughes (Cambridge, 1971), p. 76.

81 Brooks, "Military Obligations," p. 81.

82 S 1688, S 1689, S 169o; For discussions of the details of these grants and their possible locations, see Edwards, Wessex, p. 75 and Abrams, Glastonbury, p. 104, p. 141 and pp. 173-74.

83 S 152; Abrams, Glastonbury, p. 336-38. 
laying in the large episcopal estate of Bishops Cannings by Domesday; it is likely to have been a royal estate at an earlier period). Quemerford, Horton and Marten all lay on important routes.

If there is any substance in the notions offered above, then a further comment can be offered regarding one of the most celebrated entries in the AngloSaxon Chronicle, the so-called 'story of Sigeberht, Cynewulf and Cyneheard' found in the annal for $757 .{ }^{84}$ Immediately distinctive by its length, tone and detail in comparison to the brevity that otherwise typifies 8th-century Chronicle entries, the story of inter-familial feuding in the royal house of Wessex found therein is relevant to our discussion. Here is not the place to enter into a detailed consideration of all aspects of this complex entry, which has been extensively interrogated elsewhere, but views differ widely from its acceptance as a record of 8th-century events drawing on a lost source, to its fabrication by compilers of the Chronicle in the later 9th century and therefore of questionable value. ${ }^{85}$

In essence, the entry relates how in 786 Cynewulf was murdered at meretun by a force led by another West Saxon noble, Cyneheard. The event takes place at the fortified residence of a lady usually held as Cynewulf's mistress. ${ }^{86}$ Three particular aspects of the tale are relevant here: it is often considered as a description of the transition of society from a kin-based to a lordship-based one; it provides evidence for fortified estate centres in 8th century Wessex, and its location, although much-speculated upon, is unknown.

We need not comment further here on the first two issues, but we might suggest that the meretun where Cynewulf met his end is also the Mertone that features in the mid-13th-century Glastonbury Index Chartarum noted above. ${ }^{87}$ The name meretun means 'farm at the boundary'. ${ }^{88} \mathrm{~A}$ series of locations have

84 ASC s.a. 755 (for 757 ).

85 The most sceptical view is perhaps that found in H. Kleinschmidt, "The Old English Annal for 757 and West Saxon Dynastic Strife," Journal of Medieval History, 22 (1996), 209-24, while many other scholars have interrogated the entry for what it might actually reveal about 8th century familial rivalries. For a range of views on its applicability, see: Yorke, Wessex, p. 91 and pp. 286-87; Stephen D. White, "Kinship and Lordship in Early Medieval England: The Story of Sigeberht, Cynewulf, and Cyneheard," in Old English Literature: Critical Essays, ed. R.M. Luizza (New Haven, CT, 2002), pp. 157-81. Early entries in the Chronicle are discussed elsewhere in this volume by Courtnay Konshuh, "Constructing Early Anglo-Saxon Identity in the Anglo-Saxon Chronicles," above, pp. 154-180.

$86 \quad$ Yorke, Wessex, p. 79.

87 Abrams, Glastonbury, p. 35, IC B1.

88 Gover et al. Wiltshire, p. 347 and p. 402. 


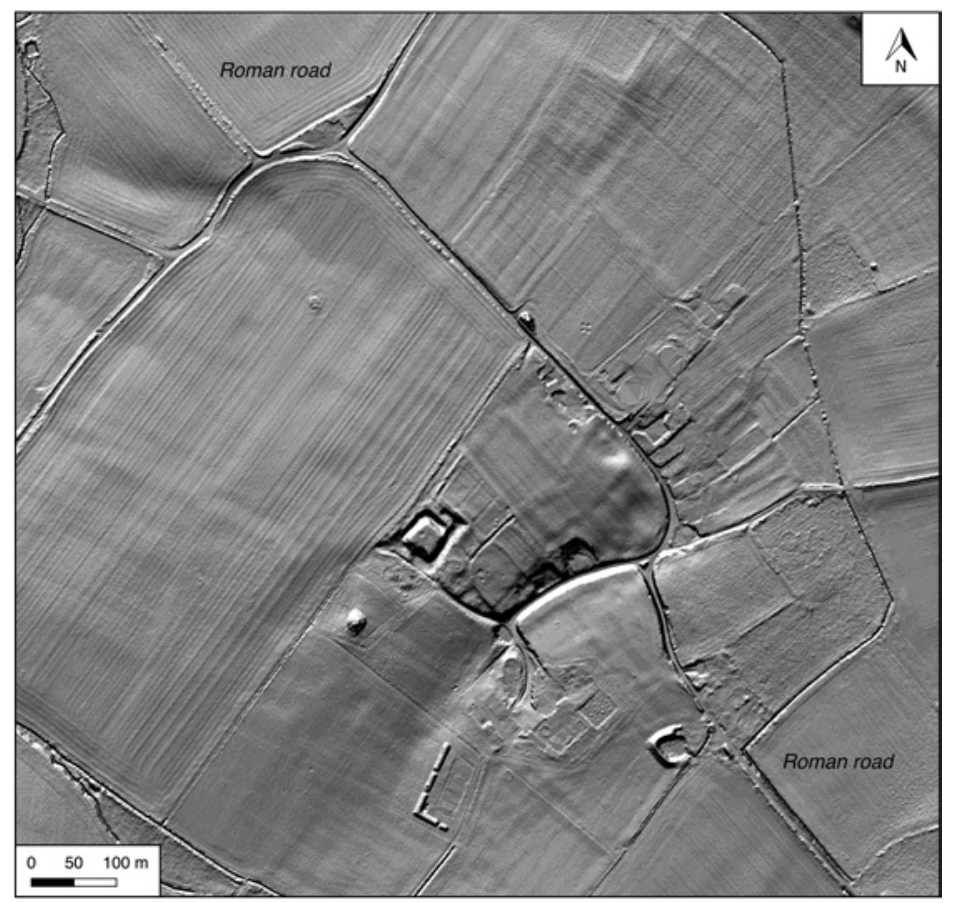

FIGURE 12.5 Earthworks from LiDAR evidence from Marten, showing the Cvnetio to Venta Roman road routed around the enclosure

been proposed, ranging from Merton in Surrey, Martin in Hampshire, Dorset or in Devon, ${ }^{89}$ but Marten in Wiltshire, is close both to the county boundary with Berkshire and Hampshire (the earliest mention of Hamtunscir is in the Chronicle entry for 757) and to the northern frontier between Wessex and Mercia in the later 8th century. Remarkably, Marten lies just short of $12 \mathrm{~km}$ south-south-east of Mildenhall, directly on the Roman road from Mildenhall to Winchester (Fig. 12.5). Merton in Surrey does not make sense in that Surrey was under Mercian control in the period during which the meretun incident occurred, ${ }^{90}$ while arguments for the other suggested sites rely solely upon place-name evidence. The Wiltshire site at least has a socio-political context in relation to Cynewulf and his followers. A further piece of evidence that suggests a familial connectionboth on the part of Cynewulf and Cyneheard - to the locality is the name of

$89 \quad$ See the list with references in White, "Kinship and Lordship," p. 174, n. 11. N.B. Martin in Hampshire was in Wiltshire until the late 19th century and is not be confused with the Wiltshire Marten discussed here.

9o J.E.B. Gover, Allen Mawer and F.M. Stenton, The Place Names of Surrey (Cambridge, 1934), xvii and p. 25. 
the hundred within which Marten lay: Kinwardstone $=$ Cyneweard's stone. ${ }^{91}$ The hundred contains substantial royal holdings, for example those of Bedwyn and Pewsey, and by the time of the Domesday Survey it was the second largest hundred in Wiltshire being assessed at $1961 / 4$ hides, ${ }^{92}$ an extent 100 hides smaller than that attributed to the lesser groupings found in the Tribal Hidage list of 7 th- or 8th-century date and it might be suggested that the hundred is in essence an early tribal/familial territory. ${ }^{93}$

Marten also has archaeological evidence for a substantial earthwork enclosure interpreted as a moat (Fig. 12.5), ${ }^{94}$ although moats, it has to be said, are rare features in the county with a distribution that places most of the 37 known sites in the north and east of the county, off the chalk and on the clay soils that characterise that part of Wiltshire. ${ }^{95}$ While settlement-related earthworks of the pre-Conquest period are rare anywhere, they do survive in the context of defensible sites. ${ }^{96}$ Besides the earthwork remains at Marten, a Google Earth search reveals evidence for a substantial double-ditched enclosure that extends beyond the upstanding features and across the field through which the Roman road passes (Fig. 12.6). Indeed, it can be seen that the Roman road has been diverted from its original course around this enclosure, while it follows a straight line before and after. A possible parallel for the form and extent of the Marten enclosure is provided by the excavated 8th-century defensible highstatus farm at Yarnton in South Oxfordshire, a site whose arguably militarised aspect may reflect its location towards the southern frontier of Mercia in that period. ${ }^{97}$ Only fieldwork will reveal Marten's secrets, but it seems as strong a candidate for the location of meretun as any other suggestion offered to date.

91 Gover et al., Wiltshire, p. 331.

92 A.P. Baggs, J. Freeman, C. Smith, J.H. Stevenson and E. Williamson, 'Kinwardstone Hundred', $v c H$ Wilts 12 , pp. $3^{-7}$, at p. 3 .

93 For an excellent discussion of Great Bedwyn and region, see Bruce Eagles, 'The Area around Bedwyn in the Anglo-Saxon Period, in The Romano-British Villa at Castle Copse, Great Bedwyn, ed. Eric Hostetter and Thomas Noble Howe (Bloomington, 1997), pp. 378-97.

$94<$ https://historicengland.org.uk/listing/the-list/list-entry/1013104> (accessed 12 Jan. 2018).

95 Mat Charlton, "Moated sites near Westbury," Camertonia $5^{1}$ (2013), 34-39.

96 See, for example, Andrew Reynolds and Stuart Brookes, "Anglo-Saxon Civil Defence in the Viking Age: A Case-Study of the Avebury Region," in Early Medieval Art and Archaeology in the Northern World: Studies in Honour ofJames Graham-Campbell, ed. Andrew Reynolds and Leslie Webster (Leiden, 2013), pp. 561-6o6.

97 Gill Hey, Yarnton: Saxon and Medieval Settlement and Landscape (Oxford, 2004), pp. 139-66; Andrew Reynolds, "Archaeological Correlates for Anglo-Saxon Military Activity in Comparative Perspective," in Landscapes of Defence in Early Medieval Europe, ed. John Baker, Stuart Brookes and Andrew Reynolds (Turnhout, 2013), p. 20. 


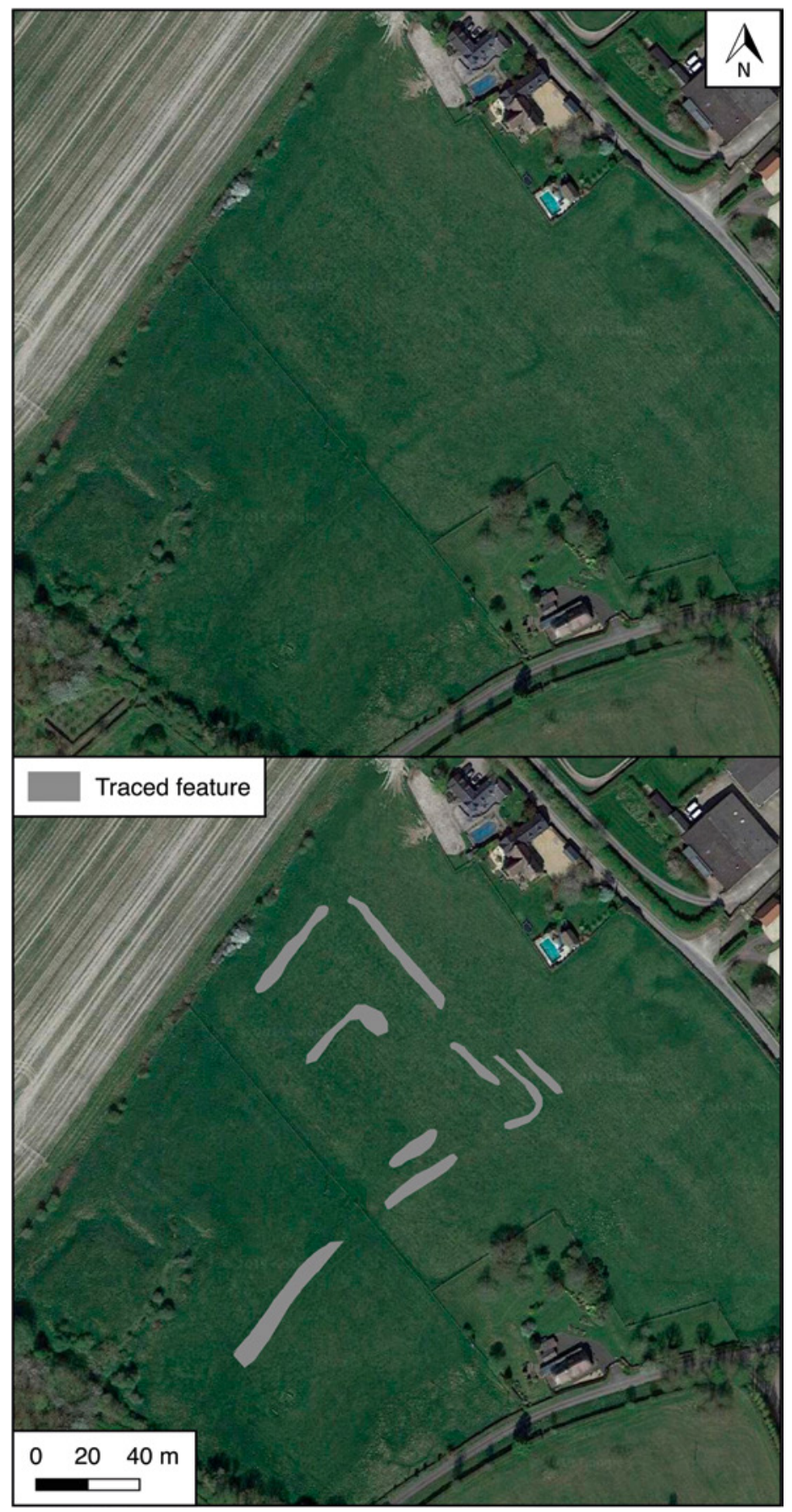

FIGURE 12.6 Aerial image of the Marten enclosure (above) with transcription (below) 
If these ideas are plausible, then they indicate a high degree of contemporary geospatial knowledge and suggest a power base for Cynewulf and his kinsmen in eastern Wiltshire. In this context, it is worth noting the rapidity with which Cynewulf's supporters managed to raise a force with which to besiege meretun and kill Cyneheard and his followers only the morning after Cynewulf's murder, while one might also expect Cynewulf's mistress to have lived in relatively close proximity to him. That the king had only a small retinue with him also perhaps indicates that he had not travelled far.

\section{Discussion}

The innovative nature of the charter tradition at this time in England is well known, ${ }^{98}$ and centres in several respects on the nature of the diplomas of Cynewulf in terms of their formulae, the introduction of detailed boundary clauses and that they include the first grants to laymen, like Bica, in Wessex. ${ }^{99}$ In an age of turbulent territorial politics, one might expect innovation in military organisation. The period from which military obligations upon lay landowners became explicit may have been preceded by a phase of reliance on kinship related networks, where obligations were considered inherent in grants of land to faithful followers that did not require explication in written form, while the late 7 th-century laws of King Ine of Wessex $(688 \times 726)$, for example, indicate that free status brought with it the requirement of military service. ${ }^{100}$

As noted above, it has long been argued (and much debated) ${ }^{101}$ — with the Anglo-Saxon Chronicle entry for 757 as a central piece of evidence-that this period witnessed a shift from kin-based loyalties to ties of lordship. Yorke notes that the granting of lands by charter could potentially seriously diminish royal authority, and there is certainly explicit evidence from Wessex in the later 9th century that King Alfred and other leading nobles were aware of this. ${ }^{102} \mathrm{On}$ the basis of the geographical distribution of Cynewulf's grants to laymen reconstructed in this paper (Fig. 12.7), however, it might be tentatively proposed that

$98 \quad$ Edwards, Wessex, p. 61.

99 Susan Kelly, Charters of Malmesbury Abbey (Oxford, 2005), pp. 170-71; Yorke, Wessex, p. 246.

100 Ine, clause 51, in Die Gesetze der Angelsachsen, ed. Felix Liebermann, 3 vols (Halle, 1903-16), 1:112-13.

101 See, for example, White, "Kinship and Lordship."

102 Yorke, Wessex, p. 246; Simon Keynes and Michael Lapidge, Alfred the Great (London, 1983), at p. 173 . 


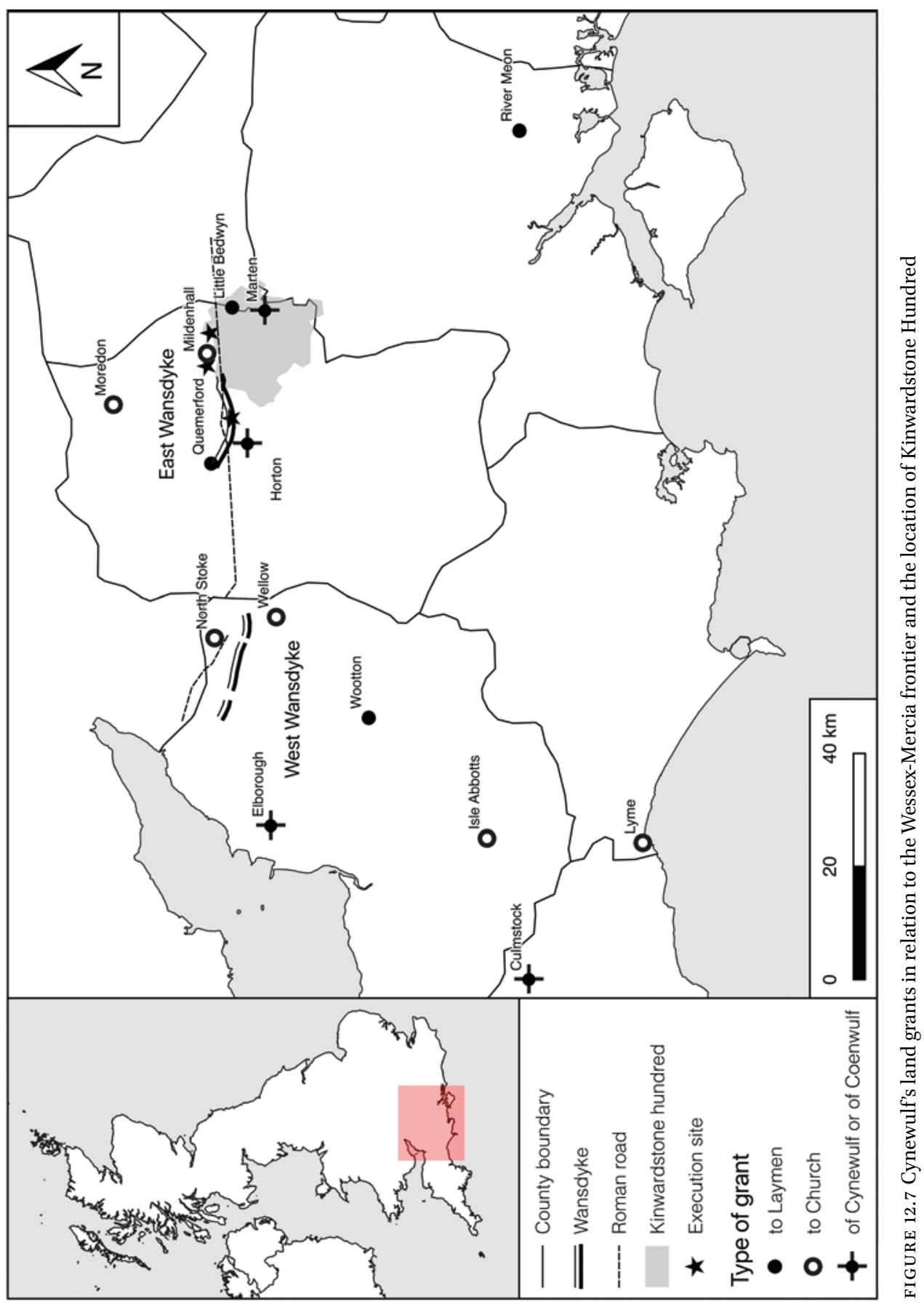


grants of strategically important lands were made with close kin as the recipients and with personal ties forming the principal bond of loyalty between king and trusted follower or relation. A century earlier, the appointment of kinsmen to sub-kingships of large regions of the early kingdom of Wessex seems to have been the norm as evidenced by the much noted granting of 3,00o hides at Ashdown (then a name applied to the Berkshire Downs) by King Cenwalh of Wessex $(642-45,648-74)$ to his nephew Cuthred. ${ }^{103}$ Cynewulf was elected by the leading councillors of the kingdom (witan $)^{104}$ indicating a degree of cohesion that had perhaps not existed immediately previously as the various branches of the West Saxon royal family had fought among themselves and it may be that he appointed faithful men as well as relations to strategically important places in the landscape but with grants of a smaller scale to those of a century earlier. The 757 ASC entry also relates how Sigeberht (brother of Cyneheard, Cynewulf's murderer), deposed as king of the West Saxons by Cynewulf, was left in control of Hampshire, a not inconsiderable region, following established practice. From which branch of the West Saxon royal family Cynewulf was sprung remains unknown, but he at least claimed ancestry from the perceived founder of the West Saxon dynasty, Cerdic. ${ }^{105}$

A further point worth noting is the longevity of Cynewulf's reign. At 31 years, his period of rule is impressive by the standards of the day, notwithstanding the long reigns of the Mercian kings Æthelbald (716-57) and Offa (757-96). In Wessex between the reigns of Cynegils (611-42) and Egbert (802-39) only the rulership of King Ine (688-726) at 37 years is longer than Cynewulf's. Cynewulf attended a meeting with papal legates in Canterbury in 786, ${ }^{106}$ apparently on an equal footing with Offa, and he appears to have enjoyed much of his reigncertainly between $75^{8}$ and 772 when he attests a charter of Offa, ${ }^{107}$ but probably until the Bensington defeat in 779 - as a (relatively) free agent, able to campaign against the western British on a frequent basis even in view of the might of his northern neighbour. ${ }^{108}$ It is perhaps this window-between 758 and 779 - that the Wansdyke frontier took its form and name. ${ }^{109}$

\footnotetext{
103 ASC s.a. 648. Yorke, Wessex, p. 83-84.

104 ASC 757.

105 Barbara Yorke, Kings and Kingdoms of Early Anglo-Saxon England (London, 1990), p. 140; ASC 757 .

$106 E H D$ 1, pp. 770-74.

$107 \mathrm{~S}$ 108, the grant of an estate at Bexhill, Sussex.

108 ASC 757. Yorke, Kings and Kingdoms, p. 105.

109 This view modifies that found in Reynolds and Langlands, "Maximum View," p. 37, where a post-Bensington context was suggested.
} 


\section{Closing Remarks}

It might be proposed that the granting of estates in the late 8th century to trusted individuals of key locales represents a concerted effort on the part of King Cynewulf to consolidate the northern frontier of his realm by a policy of strategic grants of land. Halsall notes the crucial role of the royal bodyguard in military organisation ${ }^{110}$ and if the places and events considered in this paper can indeed be spatially related in the ways suggested, then Cynewulf's personal power base might be placed in central eastern Wiltshire, perhaps with a principal residence at Bedwyn or Pewsey. ${ }^{111}$ The innovative nature of Cynewulf's charters and the context within which his military actions took place perhaps encapsulate a period of transition between the idea that military service was customary, to one where dues began to be more formally required. In an important discussion of the evolving structures of military obligation in 7 th- to 9th-century England, Nicholas Brooks recalled charters of 739 and 794 that reveal that Wessex required all men with the rank of comes (landholding warriors) to provide military service. ${ }^{112}$ Such political actions might well provide a context for the earthworks of both west and east Wansdyke, whether they are read as newly built at that time or as augmented existing features with an added ideological impact via their naming.

In conclusion, even if the Werg burials, where our enquiry began, are eventually shown to belong to the Roman period, this consideration has raised a number of questions and offered some tentative thoughts relating to the locale in the post-Roman centuries, not least a political and landscape context for two early West Saxon grants of land to Bica, 'comes', 'minister' and, it appears, appointed guardian, potentially with other men of similar standing elsewhere in the immediate locale, of key locations along the frontier between Mercia and Wessex in the late 8th century. It is possible, then to offer a tentative notion of an 8th-century Wessex that has traditionally been seen as a somewhat inferior counterpart to its northern neighbour in terms of military organisation. Rather than just coping with Mercian militarism by armed response, sometimes successful and sometimes not, perhaps Wessex also made use of powerful symbols in the landscape-gallows, fortifications and frontier earthworks - sending strong signals of authority to people within and without the consolidating polity. These actions perhaps reflect efforts by Cynewulf to

\footnotetext{
110 Guy Halsall, Warfare and Society in the Barbarian West, 450-90o (London, 2003), p. 87.

111 It might also be suggested that Sigeberht could be supervised from the relatively close quarter of the Kinwardstone territory.

112 Brooks, "Military Obligations," pp. 8o-81. S 255 and 267.
} 
ideologically cement his people via expressions of judicial and militarised authority, collective action in the creation of a frontier and the conscious implanting of a shared cultural memory by embedding perceived royal genealogy in the landscape. Overall, this piece is consciously speculative, but it is offered in the spirit of enlivening debate in a period and region about which Barbara Yorke has revealed so much, but about which so much more remains to be known. ${ }^{113}$

113 I am grateful to the editors for their invitation to contribute to this festschrift, for their forbearance in waiting for my contribution and for their comments. John Baker provided useful guidance on aspects of the place-name material. Judy Haynes, formerly of Marlborough College, very kindly provided a copy of that institution's Natural History Society Report for 1956. The illustrations were prepared by Barney Harris. 